\title{
Nuclear DNA Variation in Relation to Cytological Features of Some Species in the Genus Plantago L.
}

\author{
A. Badr ${ }^{2}$, R. Labani ${ }^{2}$ and T. T. Elkington ${ }^{3}$
}

Accepted February 20, 1986

During the last 15 years or so abundant data have been accumulated indicating that a wide variation exists among plants in the nuclear DNA content (Rees 1972, Rees and Jones 1972, Price 1976, Bennet et al. 1982). Several attempts have been made to utilise this variations in the study of species relationshpis in various taxonomic groups (Sparrow and Nauman 1974, Price and Bachman 1975, Greilhuber 1977). These studies have shown that variation in nuclear DNA content often provides useful evidence which helps to assess the relationships among related species particularly when used in combination with other features particularly cytological characters.

The genus Plantago L. (Plantaginaceae) was monographed by Pilger (1937) and was revised by Rahn (1978) who proposed some nomenclatorial changes and suggested a key for the subdivisions and some sections of the genus. The cytological studies carried out on Plantago indicate that about $70 \%$ of the species in this genus have a basic chromosome number of $\mathrm{x}=6$. and are distributed in the three subgenera of the genus. A basic number of $x=5$ was recorded in about $25 \%$ of the species in Plantago which are placed in subgenus Psyllium (Juss.). Harms and Reiche or in subgenus Coronopus (Lam and DC) Rahn. A basic number of $x=4$ is so far only recorded in two species comprising less than $2 \%$ of the genus and they are placed in subgenus Psyllium (McCullagh 1934, Rahn 1957, Fernandes and Franca 1973, Zemskova 1977).

In Egypt the genus Plantago comprises 21 species. The majority of which are found in the coastal Mediterranean region. In the present study the nuclear DNA in 9 species of the genus are measured and related to the cytological features and taxonomic relationships of the studied taxa.

\section{Material and methods}

Material of the studied species was collected from their natural habitats from various parts of Egypt. A list of these species and localities from which they were collected is given in Table 1. The distribution of localities in the different parts of Egypt is shown on the map (Fig. 1). Identification of species was made by the senior author (A. Badr) and verified by Prof. M. N. El-Hadidi, Professor of Plant Taxonomy and Head of Botany Department, Cairo University. Vouchers are kept at the herbarium of Botany Department, Tanta University.

For the determination of DNA per nucleus seeds were germinated on moist filter paper simultaneously with seeds of Allium cepa cv. Ailsa Craig which was used as a standard in the determination of the 4C DNA amounts. Root tips of samples and that of $A$. cepa were fixed in 3: 1 alcohol: glacial acetic acid for 24 hours and were then washed in distilled water, hydrolized in $1 \mathrm{~N} \mathrm{HCl}$ at $60^{\circ} \mathrm{C}$ for 10 minutes and stained in leucobasic fuchsin for 2 hours. Roots were then washed in running water for 8 minutes and in $\mathrm{SO}_{2}$ water for 30 minutes and stored in distilled water. Squash preparations were made in a drop of distilled water and coverslips

3 Botany Department, Sheffield University, England. 
were separated by quick freezing in carbon dioxide ice. Preparations were dehydrated in alcohol and mounted in euparal.

DNA measurements were carried out using a Vickers M86 scanning microdensitometer with a range of different mask sizes depending on the area of the nucleus. Measurements were made on 10 prophase nuclei per root tip and 3 root tips for each sample were used. Comparisons of the mean of these measurements with that of $A$. cepa were made and the 4C DNA amount of each species of Plantago was calculated using the following formula: 4C DNA= $\mathrm{A} / \mathrm{B} \times \mathrm{C}$ where $\mathrm{A}=$ the $4 \mathrm{C}$ DNA amount in $A$. cepa derived from $2 \mathrm{C}$ determinations (Bennet et al. 1982), $\mathrm{B}=$ the mean absorption figure measured in the $A$. cepa standard root tips and $\mathrm{C}$ $=$ the mean absorption figure measured in a species of Plantago.

Chromosome numbers and mean chromosome length of the studied species were determined in root tips pretreated with $0.05 \%$ colchicine solution and fixed in 3:1 alcohol: acetic acid. Preparations were made using the Feulgen squash method and were made permanent by mounting in canada balsam. The mean $4 \mathrm{C}$ DNA value recorded was divided by the basic number

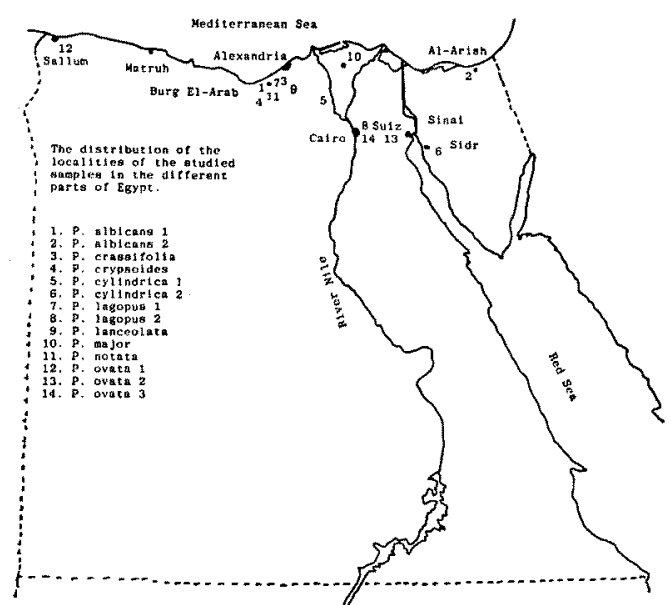

Fig. 1. of chromosomes to obtain the DNA/genome so that data of the different samples can be compared.

\section{Results and discussion}

The amount of DNA and cytological features of the 14 samples belonging to 9 species of Plantago are given in Table 1. The two samples of $P$. albicans $L$. contain the highest 4C DNA amount/nucleus among the studied species; being $7.77 \mathrm{pg}$ in sample 1 and $7.37 \mathrm{pg}$ in sample 2 respectively. Both samples are hexaploid with $2 \mathrm{n}=30$, but the karyotype of sample 2 also includes $3 B$ chromosomes. In the tetraploid $P$. crassifolia Forssk. $(2 \mathrm{n}=20)$ the recorded $4 \mathrm{C}$ DNA was $5.87 \mathrm{pg}$. In $P$. crypsoides Boiss. and the two samples of $P$. cylindrica Forssk. which are diploid $(2 n=10)$ but resemble the two previous species in having a basic chromosome number of $\mathrm{x}=5$, similar amounts of $4 \mathrm{C}$ DNA/nucleus were measured (Table 1).

The measured 4C DNA content/nucleus in two samples of $P$. lagopus $\mathrm{L}$. and in $P$. lanceolata L. both diploid with $2 \mathrm{n}=12$ and $\mathrm{x}=6$ is similar, but considerably higher than those recorded in the diploid samples with $\mathrm{x}=5$ i.e. $P$. crypoides and $\mathrm{P}$. cylindrica (Table 1). The 4C DNA content/nucleus was measured in two other diploid species with $\mathrm{x}=6$. In $P$. major $\mathrm{L}$. the measured 4C DNA amount/nucleus was $3.90 \mathrm{pg}$ which is smaller than those recorded in $P$. lagopus and $P$. lanceolata. In $P$. notata Lag., on the other hand, the highest amount of 4C DNA amount/ nucleus among the diploid species investigated $(5.73 \mathrm{pg})$ was recorded (see Table 1$)$.

The $4 \mathrm{C}$ nuclear DNA was measured in 3 samples of $P$. ovata Forssk. The two diploid samples ( 1 and 2 ) both with $2 \mathrm{n}=8$ have $2.14 \mathrm{pg}$ and $1.98 \mathrm{pg}$ DNA in the $4 \mathrm{C}$ nucleus respectively. In the tetraploid sample of this species $(2 n=16)$ a DNA amount of $3.2 \mathrm{pg}$ in the $4 \mathrm{C}$ nucleus was recorded.

The amount of DNA per genome in the two hexaploid samples of $P$. albicans and the tetraploid species $P$. carssifolia was found to be smaller than the corresponding amounts in the diploid species having the same basic number $(\mathrm{x}=5)$ i.e. $P$. crypsoides and $P$. cylindrica (Table 1). Similarly the DNA amount/genome in the tetraploid sample of $P$. ovata $(\mathrm{x}=4)$ was con- 
siderably smaller than those found in the two diploid samples of this species.

The DNA amount/genome in the species with $x=6$ was remarkably higher than those found in species with $x=5$ or $x=4$. Thus, the amount of DNA/genome is generally correlated with the basic chromosome number of the Plantago species studied. $P$. ovata with $\mathrm{x}=4$ contains the least amount of DNA/genome. Higher amounts of DNA/genome were found in the species with $\mathrm{x}=5$ i.e. $P$. albicans, $P$. crassifolia, $P$. crypsoides and $P$. cylindrica. However, the amounts of DNA/genome recorded in the species having $\mathrm{x}=6$ i.e. $P$. lagopus, $P$. lanceolata, $P$. major and notata were higher than those found in the species with $\mathrm{x}=5$ (Table 1).

It is also evident from the present data (Table 1) that the amounts of DNA/nucleus in the polyploid species i.e. $P$. albicans $(2 \mathrm{n}=30, \mathrm{x}=5), P$. crassifolia $(2 \mathrm{n}=20, \mathrm{x}=5)$ and sample of 3 of $P$. ovata $(2 \mathrm{n}=16, \mathrm{x}=4)$ have much higher DNA content compared with diploid species having the same basic number. These findings support the conclusion of Price (1976) that polyploidy may be accompanied by the duplication of nuclear DNA. However, the increase in nuclear DNA in the polyploid species is lower than expected on the basis of the ratio between the diploid and hexaploid level $(1: 3)$ as in $P$. albicans or the tetraploid level $(1: 2)$ as in $P$. crassifolia

Table 1. Localities, cytological features and DNA contents per nucleus (4C DNA), per genome in the studied species

\begin{tabular}{|c|c|c|c|c|c|c|c|}
\hline Species & Locality & $\begin{array}{l}\text { Chrom. } \\
\text { number } \\
(2 n)\end{array}$ & $\begin{array}{c}\text { Basic } \\
\text { number } \\
(\mathrm{x})\end{array}$ & $\begin{array}{c}\text { Ploidy } \\
\text { level }\end{array}$ & 4C DNA & $\begin{array}{l}\text { DNA/ } \\
\text { genome }\end{array}$ & $\begin{array}{l}\text { Mean } \\
\text { chrom. } \\
\text { length } \\
\text { in } \mu \mathrm{m}\end{array}$ \\
\hline 1. P. albicans 1 & Burg El-Arab & 30 & 5 & $6 x$ & 7.77 & 1.29 & 3.44 \\
\hline 2. P. albicans 2 & Sinai, El-Arish & $30+3 B$ & 5 & $6 x$ & 7.37 & 1.23 & 3.62 \\
\hline 3. P. crassifolia & $25 \mathrm{~km}$ West Alex. & 20 & 5 & $4 x$ & 5.87 & 1.47 & 2.90 \\
\hline 4. P. crypsoides & Burg El-Arab & 10 & 5 & $2 x$ & 3.68 & 1.88 & 2.55 \\
\hline 5. P. cylindrica 1 & 140 km South Alex, & 10 & 5 & $2 \mathrm{x}$ & 3.30 & 1.65 & 3.03 \\
\hline 6. P. cylindrica 2 & Sinai, Sidr & 10 & 5 & $2 x$ & 3.84 & 1.97 & 3.13 \\
\hline 7. P. lagopus 1 & Burg El-Arab & 12 & 6 & $2 x$ & 4.61 & 2.31 & 2.40 \\
\hline 8. P. lagopus 2 & Madinet Qasr, Cairo & 12 & 6 & $2 x$ & 5.00 & 2.50 & 2.62 \\
\hline 9. P. lanceolata & 25 km South Alex. & 12 & 6 & $2 \mathrm{x}$ & 5.16 & 2.58 & 2.96 \\
\hline 10. P. major & Kafr El-Sheikh & 12 & 6 & $2 \mathrm{x}$ & 3.82 & 1.91 & 2.04 \\
\hline 11. P. notata & Burg El-Arab & 12 & 6 & $2 x$ & 5.73 & 2.87 & 4.01 \\
\hline 12. P. ovata 1 & Sallum & 8 & 4 & $2 \mathrm{x}$ & 2.14 & 1.07 & 3.04 \\
\hline 13. P. ovata 2 & $50 \mathrm{~km}$ East Cairo & 8 & 4 & $2 \mathrm{x}$ & 1.98 & 0.99 & 3.13 \\
\hline 14. P. ovata 3 & Madinet Nasr, Cairo & 16 & 4 & $4 x$ & 3.20 & 0.80 & 3.22 \\
\hline
\end{tabular}

or $P$. ovata. The ratio between the nuclear DNA in $P$. crypsoides $(2 \mathrm{n}=10, \mathrm{x}=5)$ and the average amount of the two samples of $P$. cylindrica $(2 \mathrm{n}=10, \mathrm{x}=5)$ and that in $P$. albicans are $1: 2.06$ and $1: 2.17$ respectively. The ratio between the nuclear DNA in these two species and that found in $P$. crassifolia are $1: 1.6$ for $P$. crypsoides and $1: 1.68$ for $P$. cylindrica. The ratio between the average nuclear DNA of the two diploid samples of $P$. ovata and the tetraploid sample of the same species is $1: 1.55$. Similar results were found among diploid and hexaploid plants of Betula (Taper and Grant, 1973). These authors reported a ratio of 1:2.19 between diploid $(2 \mathrm{n}=28)$ and hexaploid $(2 \mathrm{n}=84)$ plants of Betula.

$P$. albicans and $P$. cylindrica are taxonomically grouped together in subgenus Psyllium (Juss.) Harms \& Reiche and also in the same section Albicans Barns and the same series Albicantes (Rahn 1978). P. ovata is also placed in subgenus Psyllium section Albicans but in series Ovatae. Thus the similarities in the DNA amount/genome between these species support their taxonomic affinities based on morphological criteria. P. crassifolia, on the other hand, is placed in subgenus Coronopus (Rahn 1978), whereas $P$. crypsoides is morphologically different 
from $P$. albicans and $P$. cylindrica. The sectional delimitation of $P$. crypsoides, however, needs further investigation.

$P$. lagopus and $P$. lanceolata share several morphological and cytological criteria and also have similar amounts of nuclear DNA. P. lanceolata is placed in subgenus Psyllium and is considered to be the type species of section Lanceifolia Barns. In view of the similarities between these two species $P$. lagopus may be placed in section Lanceifolia of subgenus Psyllium. $P$. notata contains a nuclear DNA amount which is to some extent similar to that recorded in $P$. lanceolata. $P$. notata, however, is cytologically characterized by having longer chromosomes when compared with other species with $\mathrm{x}=6$ and is morphologically distinct from them by its penatifid leaves and wooly spikes. The sectional delimitation of this species is yet to be made.

$P$. major also with $2 \mathrm{n}=12$ and $\mathrm{x}=6$, on the other hand, contains smaller amount of nuclear DNA if compared with other species having $\mathrm{x}=6$. Cytologically this species is characterized by short chromosomes and symmetric karyotype. Morphologically $P$. major is also distinct by its 3-9 veined, broad, ovate, glabrous leaves, narrow, green, long spikes and its affinity to grow in moist places. Taxonomically this species is separated from the other studied species and is placed in subgenus Plantago by both Pilger (1937) and Rahn (1978). Based on the present results and the morphological and cytological criteria the separation of $P$. major seems justified.

The basic chromosome number of $\mathrm{x}=6$ is the most common among the species of Plantago and may be considered the ancestoral number in the genus (Setbbins and Day 1967). The basic number of $x=4$ may represent the end point of a stepwise reduction in the basic number. A similar pattern of change in the nuclear DNA may be deduced from the present results. Species with $\mathrm{x}=6$ have considerably higher amounts of nuclear DNA in comparison to those with $x=5$ or $x=4$, whereas species with $x=4$ have the least amount of nuclear DNA. It is therefore suggested that the reduction in chromosome number has been associated with a reduction in the amount of nuclear DNA.

\section{Summary}

The nuclear DNA content in 14 taxa belonging to 9 species of Plantago from Egypt has been measured using cytophotometric methods. The recorded DNA amounts were related to the karyotype features of the studied species. In general the amount of nuclear DNA/genome is correlated with the basic chromosome number. Species having $\mathrm{x}=6$ i.e. $P$. lagopus, $P$. lanceolata, $P$. major and $P$. notata contain higher amounts of nuclear DNA/genome when compared with the species having $\mathrm{x}=5$ i.e. $P$. albicans, $P$. crassifolia, $P$. crypsoides and $P$. cylindrica. Three samples of $P$. ovata $(\mathrm{x}=4)$ were found to contain the least amounts of DNA/genome. It was also found that polyploid taxa contain higher amounts of $4 \mathrm{C}$ DNA/nucleus than diploid species. The impact of these results on the taxonomic relationships of the studied species is discussed.

\section{References}

Bennet, M. D., Smith, J. B. and Heslop-Harrison, J. S. 1982. Nuclear DNA amounts in Angiosperms. Proc. R. Soc. Lond. B 216: 179-199.

Fernandes, A. and Franca, F. 1973. Contribution à la connassisance cytotaxonomique des Spermatophyta du Portugal VI. Plantaginaceae. Bol. Soc. Brot. 46: 465-501.

Greilhuber, J. 1977. Nuclear DNA content and heterochromatin contents in the Scilla hohenackeri group, S. persica and Puschkivia scilloides (Liliaceae). Plant Syst. Evol. 128: 243-257.

McCullagh, D. 1934. Chromosome numbers and chromosome morphology in Plantaginaceae. Genetica 16: $1-44$.

Pilger, R. 1937. Plantaginaceae. In Engler and Diels. Das Pflanzereich Vol. 4. W. Engelman Leipzig.

Price H. J. 1976. Evolution of DNA content in higher plants. Bot. Rev. 42: 28-4. 
- and Bachman, K. 1975. DNA content and evolution in the Microseridenae. Amer. J. Bot. 62: 262-267.

Rahn, K. 1957. Chromosome numbers in Plantago. Bot. Tidsskr. 53: 369-378.

- 1978. Nomenclatorial changes within the genus Plantago L. Infraspecific taxa and subdivisions of the genus, Bot. Tidsskr. 73: 106-111.

Rees, H. 1972. DNA in higher plants. Brookhaven Symp. Biol. 23: 394-418.

- and Jones, R. N. 1972. The origin of the wide species variation in nuclear DNA content. Intern. Rev. Cytol. 32: 53-92.

Sparrow, A. H. and Nauman, A. F. 1974. Evolutionary changes in genome and chromosome sizes and DNA content in the grasses, Brookhaven Symp. Biol. 25: 267-389.

Stebbins, G. L. and Day, A. 1967. Cytogenetic evidence for long continued stability in the genus Plantago. Evolution 21 : 409-428.

Taper, L. J. and Grant, W. F. 1973. The relationship between chromosome size and DNA content in Birch (Betula) species. Caryologia 26: 263-273.

Zemskova, E. A. 1977. Karyological study of some species of Plantago L. (Plantaginaceae). Bot. Znurna 1 62: 1301-1305. 